\title{
AdVERTISING AN EMPIRE OF OIL: The British Petroleum Company ANd the Persian KHAN EXHIBIT OF 1924-1925
}

\author{
IAN WERELEY
}

\section{Introduction}

Responding to the rapid expansion in the use of automobiles in Britain during the early 1920s, oil companies began to sell motor spirit (gasoline) in ever increasing quantities. Competition among the major distributors was fierce and the public soon found itself assailed by an array of colourful, eye-catching marketing. One of the most innovative oil advertisers during this period was the British Petroleum Company [BP]. BP was the marketing, sales, and distribution subsidiary of the Anglo-Persian Oil Company [APOC], a British-owned oil exploration and extraction company with a large concession in the mountains of south-western Persia. In order to increase its share of the ever-expanding British motor spirit market, and to maximize profits for its parent company, BP invested in a variety of elaborate advertising campaigns during the mid-1920s.

The largest and most expensive of these campaigns was the Persian Khan exhibit, mounted at the British Empire Exhibition [BEE] of 1924-1925. The Khan was an oil spectacle in every way, designed to resemble an elaborate caravanserai, the traditional structure used to accommodate travellers making their way through the Persian desert. Inside the exhibit, visitors learned about BP's products and the modern oil science and technology that had produced them. The information was conveyed through a series of mahogany display cases, which were filled with artefacts, photographs, and examples of oilburning technologies. Further assistance was provided by BP interpreters, who distributed colourful sales brochures and other promotional materials.

Using a variety of primary sources, this article explores the ways in which BP's Khan exhibit represented Persia, its people, and its oil resources. What images and ideas did BP use to tell its story of oil, and how were these narratives brought to life? Employing the perspective of the Energy Humanities, the article focuses on the ways in which BP's Khan exhibit worked 
to influence the imagination of the motoring public, and to shape the development of early British attitudes towards oil. It shows that the Khan rendered an imaginary world in which oil was framed as an exotic subterranean prize held captive beneath wild and inhospitable landscapes which, with modern science and technology, had been unlocked by BP and its parent company, APOC. In this teleological story of discovery and exploitation, the British motorist was configured as the central character and the deserving heir to the buried natural treasure.

Despite their rich value as primary sources, the marketing campaigns of British oil companies - and in particular of $\mathrm{BP}$ - have been relatively overlooked by historians. ${ }^{1}$ Curiously, few studies of oil have approached the resource as a phenomenon which has been constructed by and through cultural processes. Indeed, as the editors of a special volume on contemporary oil cultures in the Journal of American Studies lamented in 2012, "the humanities have not had much to say about oil until recently."2 Cultural historians and geographers, in particular, have been actively revising oil narratives in recent years. Critical geographers Simon Dalby and Matthew Paterson, for example, have investigated the discursive legacies of petro-imperialism that exist in contemporary car advertisements, including geographical domination of distant places and assertions about the inherent right of consumption. ${ }^{3}$ Cultural theorists interested in oil and its multiple pasts, such as Robert Johnson, Imre Szeman, and Stephanie LeMenager, have investigated the historical origins of oil discourses, specifically those which circulated within North America during the nineteenth and twentieth centuries, raising searching questions about the

\footnotetext{
${ }^{1}$ Marian Kent's Oil and Empire (1976) and Geoffrey Jones's The State and the Emergence of the British Oil Industry (1981) both feature extensive analysis of the development of BP's management structure and contractual relationships during the 1920s, but they contain no references to marketing or advertising. Robert Brown has conducted research on the outdoor advertising campaigns of British oil companies during the interwar years, but pays scant attention to BP advertising. Marian Kent, Oil and Empire: British Policy and Mesopotamian Oil, 1900-1920 (London: Macmillan, 1976); Geoffrey Jones, The State and the Emergence of the British Oil Industry (London: Macmillan, 1981); Robert Brown, "Cultivating a 'Green' Image: Oil Companies and Outdoor Publicity in Britain and Europe, 1920-1936," Journal of European Economic History 22, no. 2 (Fall 1993): 350.

${ }^{2}$ Ross Barrett and Daniel Worden, “Oil Culture: Guest Editors' Introduction," Journal of American Studies 46 (2012): 269.

${ }^{3}$ Matthew Paterson and Simon Dalby, "Empire's Ecological Tyreprints," Environmental Politics 15 (2006): 2-3.
} 
ontology of oil and the different ways that people have come to understand the resource as being both a physical object and a cultural imaginary. ${ }^{4}$

An important recent contribution to research on the culture of oil is Ross Barrett and Daniel Worden's edited collection of essays, Oil Culture, which marks the emergence of a new body of literature "attentive to oil's cultural presence in the various social, economic, and political realms that constitute the global petroleum system." As they aptly note, humanities scholars must work to disentangle the "many dimensions of oil's cultural existence" by assessing the resource "as both an industry and a culture, a business and a set of aesthetic practices, a natural resource and a trope." inherently unstable and unfinished artefact that is constructed by the consumer and the culture in which they exist - as something that is brought to life through discourse rather than drilling, through conversation rather than chemistry. BP's Persian Khan exhibit provides a valuable case study for enriching scholarly understandings of how oil was imagined in mid-1920s Britain, and a useful lens through which to view the broader development of British attitudes toward oil during the period.

\section{The British Petroleum Company and the Development of a Marketing Strategy, 1918-1924}

By 1920, BP employed some 3,000 British workers, operated 850 supply depots, and serviced one third of the overall British motor spirit market. ${ }^{7}$ In order to maintain this significant market share, and to increase profits for its parent company, the members of BP's new board of directors devised a comprehensive strategy for marketing APOC's motor spirit products in Britain. In charge of this mission was BP's General Manager, W.T. Watts, whose personal correspondence with other BP executives during this period reveals much about the evolution of the company's earliest marketing activities. In a letter written in January 1920 to a fellow board member, H.E. Nichols, Watts

\footnotetext{
${ }^{4}$ Robert Johnson, Carbon Nation: Fossil Fuels in the Making of American Culture (Lawrence, KS: University Press of Kansas, 2014); Imre Szeman, "How to Know About Oil: Energy Epistemologies and Political Futures," Journal of Canadian Studies 47 (2013): 145-68; Stephanie LeMenager, Living Oil: Petroleum Culture in the American Century (New York: Oxford University Press, 2014).

${ }^{5}$ Ross Barrett and Daniel Worden (eds.), Oil Culture (Minneapolis, MN: University of Minnesota Press, 2014): xxiii.

${ }^{6}$ Barrett and Worden, 2014, xxi.

${ }^{7}$ Ferrier, "Petrol Advertising in the Twenties and Thirties: The Case of the British Petroleum Company," European Journal of Marketing 20, no. 5 (1986), 29.
} 
complained that the company had "nothing of interest to show" its customers, except "a few balance sheets. We have not even a decent set of photographs," he lamented. ${ }^{8}$ At the $104^{\text {th }}$ Meeting of the BP Board, held in London in September 1920, Watts urged his colleagues to invest in a campaign designed to "arouse demand" for BP motor spirits, and to increase "our infant organization's place on the market." $\mathrm{BP}$ executives left the board room in agreement that "our advertising must be on a very extensive scale indeed."10

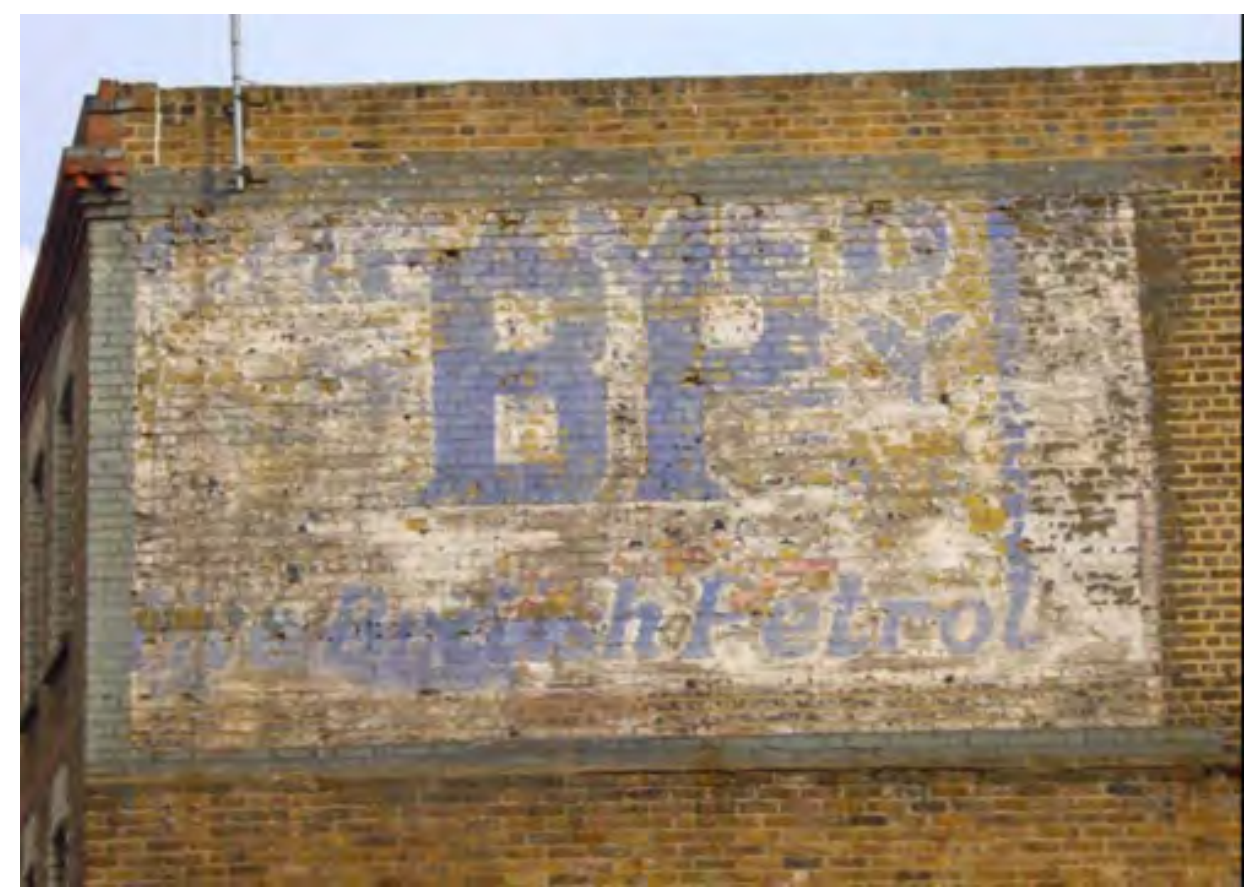

Figure 1: BP motor spirit sign (ca. early 1920s), King's Cross, London ${ }^{11}$

The first steps taken by BP occurred in February 1921, with the creation of a new Publicity Department charged with the task of increasing public demand for its oil products. Shortly after its formation, however, Watts was transferred to APOC, and another board member, W. D. Braithwaite, was put in charge of publicity. ${ }^{12}$ In the months leading up to the summer driving season of

\footnotetext{
${ }^{8}$ Correspondence of W.T. Watts, British Petroleum Co., 1919-1922. ARC 70007. W. T. Watts was General Manager of BP until 1921, when he was transferred to the Anglo-Persian Oil Company. H. E. Nichols was Director of the Board of BP from 1915-1927.

${ }^{9} 104^{\text {th }}$ Meeting of the Board, 21 September 1920.

${ }^{10}$ See note 9 .

11 "Ghost sign: BP," History of Advertising Trust, 2018. HAT60/171.

${ }^{12} \mathrm{~W}$. D. Braithwaite was a founding Director of BP and in charge of advertising and marketing during the early 1920s. Ferrier, 1982, 305.
} 
1921, it was Braithwaite who initiated the first major marketing campaign in BP's post-war history - an outdoor advertising blitz, which resulted in the erection of 12,000 enamelled-iron signs, 6,000 outdoor sign boards, and many thousands more posters in train stations, along rural and urban roadways, and at private garages across the country. ${ }^{13}$ These signs and posters were simple yet effective in their design, displaying the company's distinctive "BP" logo and often directions to the nearest filling station. [Figure 1]. The inaugural marketing campaign was a tremendous success, and Braithwaite informed his colleagues on the board that the activities of the new Publicity Department had "materially helped sales." 14 An additional budget of $£ 20,000$ (the 2018 equivalent of $£ 1$ million) was approved for the 1922 marketing campaign. ${ }^{15}$

Braithwaite used his enlarged marketing budget to develop new methods of catching the attention of British consumers. He began distributing promotional materials to private garages and filling stations, including illustrated booklets and pamphlets; road maps and driving guides; branded stationary and sundry novelty items. ${ }^{16}$ The Publicity Department also began experimenting with illuminated roadside signs, as well as reflective "light catching" signs in places where artificial light was not permitted, most particularly in rural villages. ${ }^{17}$ In addition to these stationary outdoor advertisements, BP deployed several forms of mobile oil marketing during the early 1920s. The company placed advertisements on London city buses, and branded its fleets of oil tankers, rail tank-cars, and motorized delivery vehicles with the company's "BP" logo. ${ }^{18}$ The most common form of outdoor advertising undertaken by BP was circulation of the company's 2-gallon motor spirit cans, which were used to distribute BP products across the country. ${ }^{19}$

In August 1922, just two years after Watts had first expressed his concerns about the BP's near-complete lack of marketing materials, Braithwaite reported to BP's board that "most of the country... [was] fairly well covered" in

$13104^{\text {th }}$ Meeting of the Board, 21 September 1920; $126^{\text {th }}$ Meeting of the Board, 3 August 1922.

${ }^{14} 114^{\text {th }}$ Meeting of the Board, 19 July 1921.

${ }^{15} 116^{\text {th }}$ Meeting of the Board, 25 October 1921.

${ }^{16} 111^{\text {th }}$ Meeting of the Board, 19 April 1921; $122^{\text {nd }}$ Meeting of the Board, 21 February 1922;

Wells Journal, 11 August 1922, 5.

${ }^{17} 131^{\text {st }}$ Meeting of the Board, 23 January 1923; 134 ${ }^{\text {th }}$ Meeting of the Board, 22 May 1923; Brown, 1993, 348-349.

${ }^{18} 126^{\text {th }}$ Meeting of the Board, 3 August 1922; $151^{\text {st }}$ Meeting of the Board, 22 October 1924.

${ }^{19} 161^{\text {st }}$ Meeting of the Board, 22 July $1925 ; 166^{\text {th }}$ Meeting of the Board, 21 January 1926 . By 1925 there were estimated to be over two million of the Company's 2-gallon cans circulating in Britain, all stamped with the letters "BP." 
the company's outdoor advertising. ${ }^{20}$ For his efforts, Braithwaite was rewarded with a budget increase for 1923, which board members raised by a factor of six, to $£ 120,000$ (the 2018 equivalent of $£ 6.2$ million). ${ }^{21}$ In the spring of 1923 , flush with funding, Braithwaite ordered a major restructuring of the Publicity Department, with changes ranging from a new name (the Advertising Department) to the hiring of a "highly qualified advertising expert." 22 The following year, the Department held a competition among BP employees to develop a new company logo, which was won by a distribution clerk. The design added accentuated serifs to the existing "BP" logo, and was applied to company buildings, delivery vehicles, rolling stock, and oil carrying vessels, as well as motor spirit pumps, letterheads, dividend reports, and print advertisements. ${ }^{23}$ The restructuring and rebranding were successful in further driving up sales of BP products, and by 1925 the advertising budget was $£ 175,500$ (the 2018 equivalent of $£ 9.2$ million). ${ }^{24}$

In 1923, Braithwaite initiated another major shift in BP's print advertising strategy, namely, a pivot toward the remote source of the company's oil supplies-Persia_-setting BP apart from its competitors. As Braithwaite later explained to his colleagues on the board that BP's association with APOC and its Persian crude oil was a "great advertising asset." ${ }^{25}$ In the spring of 1923, the words "Anglo-Persian Oil Company" began appearing on BP stationary, a move designed to create "a closer association in the mind" between Persia and BP motor spirit. ${ }^{26}$

Stories about Persia also began appearing in BP print advertisements. One of the earliest examples was published in several British newspapers and magazines in September. ${ }^{27}$ Entitled "From Persia to You," the advertisement used a combination of images and text to tell the story of BP motor spirits making their way from the crude wells in Persia to the filling station in Britain. A series of illustrations depicted this journey, including oil derricks set against a mountainous backdrop in Persia and local Persian workers guiding a team of

${ }^{20} 126^{\text {th }}$ Meeting of the Board, 3 August 1922.

${ }^{21}$ The total expenditure on advertising in the United Kingdom for 1923 was $£ 175$ million, which in 2018 figures is the equivalent of $£ 9.7$ billion.

$22134^{\text {th }}$ Meeting of the Board, 22 May 1923; 145 ${ }^{\text {th }}$ Meeting of the Board, 19 March 1924.

${ }^{23} 159^{\text {th }}$ Meeting of the Board, 20 May 1925; Ferrier, 1986, 36.

${ }^{24} 144^{\text {th }}$ Meeting of the Board, 19 February $1924 ; 157^{\text {th }}$ Meeting of the Board, 25 March 1925; $159^{\text {th }}$ Meeting of the Board, 20 May 1925.

${ }^{25} 160^{\text {th }}$ Meeting of the Board, 24 June 1925.

${ }^{26} 133^{\text {rd }}$ Meeting of the Board, 20 March 1923.

27 "From Persia to You," Illustrated London News, 1 September 1923. 
donkeys laden with sections of pipeline. In the accompanying text, the reader was brought back "[m] any centuries ago," to a period in which "FireWorshippers built their temples near the Petroleum springs of Persia." ${ }^{28}$ In this remote age, the advertisement explained, oil was used in primitive ways; Persians "rubbed petroleum on their camels. They even drank it as a medicine." 29 The advertisement informed readers that the high point of Persian culture had long since passed, but fortunately for British motorists, Persia's barren landscapes had been transformed by BP's use of twentieth century technology. The prize of this commercial conquest was "precious oil in an unending stream," which APOC and BP delivered directly to local garages across the country. ${ }^{30}$ The underlying message of "From Persia to You" was that the Persian origins of BP motor spirit made it stand out among its competitors, providing the motorist with an exotic, powerful, and almost magical fuel"clear, white, volatile, and ready for the electric spark to transmute it into pure energy." 31

BP's Persian-inspired advertisements clearly demonstrate how the company endeavoured to represent Persia as a peripheral space harbouring immense quantities of a magical prize that was simply there for the taking - oil. The text of the advertisements constructed an imperialistic discourse of oil that was saturated with notions of western cultural superiority, technical hegemony, and unrestricted licence to dominate the natural environments where oil was found. Crucially, these advertisements framed conversations about oil using the imaginary binaries of the ancient and the modern, the wild and the civilized, the urban and the empty.

\section{The Persian Khan:}

\section{British Petroleum and the British Empire Exhibition, 1924-1925}

In February 1924, BP began preparations for its largest and most elaborate motor spirit marketing campaign of the 1920 s - the Persian Khan exhibit. ${ }^{32}$ The Khan was the capstone achievement of Braithwaite's restructured Advertising Department, and the culmination of BP's Persian-inspired messaging strategy. The installation took the form of a large Khan, or caravanserai, the traditional

${ }^{28}$ Illustrated Sporting and Dramatic News, 29 September 1923, 49.

${ }^{29}$ Illustrated London News, 1 September 1923.

${ }^{30}$ See note 28.

${ }^{31}$ Tatler, 5 September 1923.

$32137^{\text {th }}$ Meeting of the Board, 24 September $1923 ; 156^{\text {th }}$ Meeting of the Board, 18 February 1925; $157^{\text {th }}$ Meeting of the Board, 25 March 1925. 
structure used by travellers to rest and recover as they travelled across the Persian desert. Inside the Khan, visitors learned about Persia and its oil resources by engaging with BP interpreters and a series of marketing initiatives, including illustrated pamphlets, display cases filled with information and artefacts, and artwork displaying scenes of Persian geography, history, and culture. The exhibit was an oil spectacle in every way: bold, eye-catching, and extravagant.

Taking place during the summer months of 1924 and 1925, the BEE was the largest public event held in Britain during the interwar period. ${ }^{33}$ Staged on a 220 -acre plot of land in the north-London suburb of Wembley, the BEE was designed to showcase the scientific, technological, and commercial achievements of the British Empire. ${ }^{34}$ The architectural projects undertaken at the exhibition were defined by superlatives: the Palace of Engineering was the largest concrete building in the world, and the Wembley Stadium the largest sports arena in existence. ${ }^{35}$ As Anne Clendinning has written, the BEE was "[p]art trade fair and part theme park," featuring dozens of pavilions and exhibition halls, as well as restaurants, cinemas, an amusement park, and an artificial lake equipped with gondolas for hire. The 24 kilometres of streets that connected the exhibition halls were designed to resemble the cross of St. George, and they carried names chosen by Rudyard Kipling, the poet of Empire: Union Approach, Atlantic Slope, Dominion Way. ${ }^{36}$

The BEE was an ideal venue for BP to promote its oil products. According to J. M. MacKenzie, it was "the greatest of all the imperial exhibitions - in area, cost, extent of participation, and, probably, popular impact." 37 The overall attendance at the event amounted to more than 24 million people. ${ }^{38}$ In addition, the BEE showcased a range of modern new technologies, particularly those related to transportation. ${ }^{39}$ Oil-powered vehicles

${ }^{33}$ United Empire 10 (1924): 570; T. Clarke, "British Empire Exhibition: Second Phase," $19^{\text {th }}$ Century (February 1925): 175; Alexander C.T. Geppert, Fleeting Cities: Imperial Expositions in fin-de-Siècle Europe (London: Palgrave Macmillan, 2010): 145-46.

${ }^{34}$ George Lawrence (ed.), Official Guide to the British Empire Exhibition (London: Fleetway, 1924): 7.

${ }^{35}$ Lawrence, 37; Geppert, 146.

${ }^{36}$ Anne Clendinning, "Exhibiting a Nation: Canada at the British Empire Exhibition, 19241925," Social History 39, no. 77 (2006): 79-107; “St. George's Day Lessons," The Times, 23 April 1924, 11.

${ }^{37}$ John M. MacKenzie, Propaganda and Empire: The Manipulation of British Public Opinion, 1880-1960 (Manchester: Manchester University Press, 1984): 108.

${ }^{38}$ Geppert, 2010, 146.

${ }^{39}$ Clendinning, 2006, 79-107. 
featured prominently at the exhibition, especially at the Motor and Cycle Section, where visitors could inspect "every type of car and cycle, as well as tractors, marine and aero engines, and steam and electric motor vehicles." $40 \mathrm{BP}$ also benefited from the extensive publicity that attended the BEE. The Official Guide was saturated with notions of cultural collision, modern science and technology, and industrial progress, all of which fit seamlessly into the narratives being developed in BP's Persian-inspired marketing campaigns. In this "Empire City," the Official Guide proclaimed, one could see "the latest marvels of Western science" alongside the "splendours of the markets of the East and the simple fairs of primitive peoples." 41

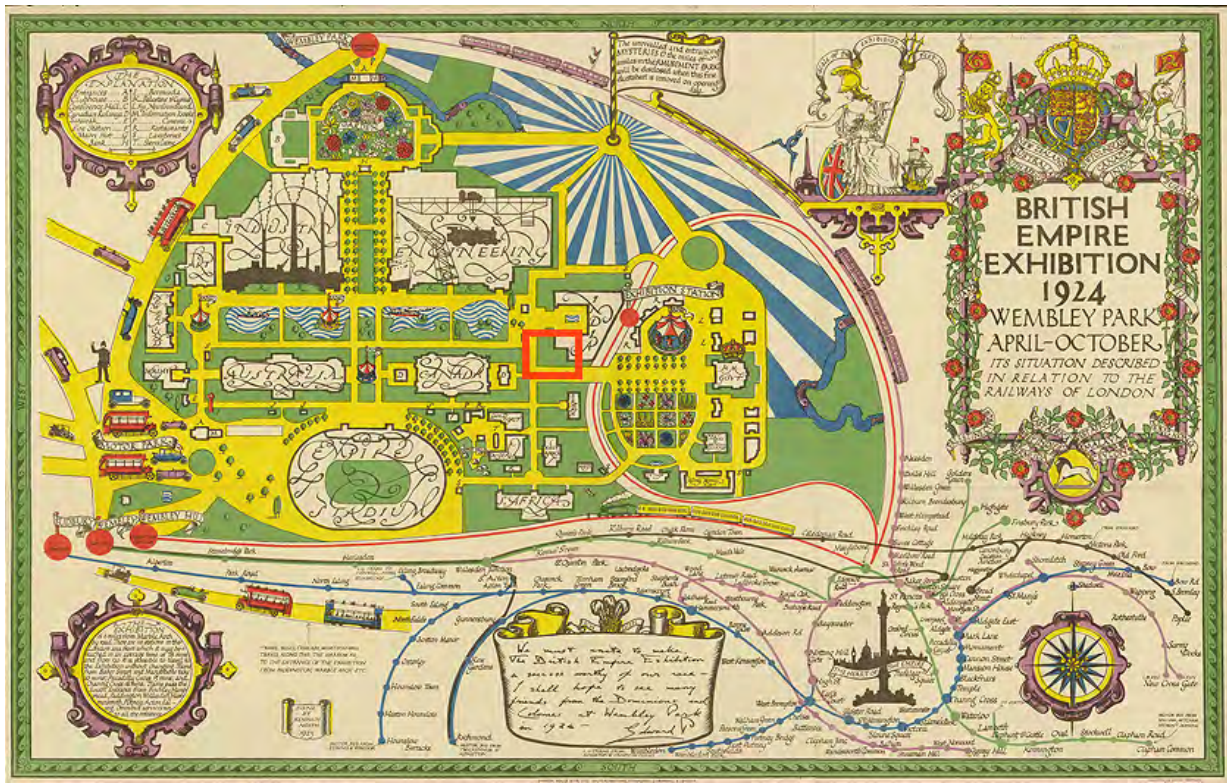

Figure 2: Official Map of British Empire Exhibition (1924), with location of BP's Persian Khan exhibit outlined in red

BP capitalized on the marketing opportunities presented by the BEE. The Persian Khan exhibit took the form of a square, two-storey building designed in classical Persian architectural style, defined by simple, block-like forms, crenelated rooflines, and arched entryways and windows. Four slender minarets of 40 feet in height were placed at the corners of the building, each of which featured a gallery at the three-quarter mark and a pointed dome on top. Three high-arched doorways marked the western, southern and eastern facades,

${ }^{40}$ Official Guide to the British Empire Exhibition, 1924, 51; British Empire Exhibition, Official Map (London: Dobson, Molle \& Co, 1924).

${ }^{41}$ Official Guide, 1924, 22. 
each of which was set in an elaborately-decorated recess. These portal-like openings were vaulted in the decorative muqarnas style common to Islamic architecture, and were flanked by two arched windows, also set in recesses and filled with an intricately-patterned screen that obstructed the view to the inside. Perhaps the most compelling feature of the exhibit's exterior was its brightlycoloured walls - adorned in tiles arranged in tessellated, and distinctly Persian, geometric patterns. A BP motor spirit delivery wagon, branded with the company's logo, was permanently stationed in front of the Khan-except when, twice daily, the wagon was driven around the exhibition grounds, supplying fuel oil to the Palace of Engineering and Palace of Industry buildings. ${ }^{42}$ The Khan itself was ideally located along the main pedestrian walkway, placed between the Canada and India Pavilions and directly in front of His Majesty's Government's Pavilion. [Figure 2].

The Persian Khan exhibit was the ultimate expression of oil advertising. The narratives of ancient Persia were continued inside the exhibit, where the messaging techniques developed in BP's print advertising campaigns were utilized to full effect. Upon arrival, visitors were approached by BP sales representatives and exhibit interpreters who distributed postcards featuring an artist's rendition of the Khan. ${ }^{43}$ [Figure 3]. The visitor's experience was centred upon a series of educational display cases, which were tucked into ornately decorated vaulted alcoves located in the centre of each interior wall. Inside the showcases were samples of BP's refined oil products, examples of kerosene lamps and other oil-burning technologies, and a variety of photographs of APOC and BP commercial activities in Persia and in Britain.

The most commanding feature of the interior of the Khan was a large, ten-sided mahogany showcase, placed in the centre of the exhibition space and clearly visible from all sides. [Figure 4]. The display featured back-lit illustrations, photographs, and dioramas that told the story of how BP products made their way from the oilfields in Persia to the filling stations in Britain. According to BP's internal staff magazine, the Naft, the diorama was presented "in proper sequence, so that a visitor walking around the exhibit sees a complete pictorial representation of the course of oil from the wells in Persia to its delivery to the customer as 'BP' Motor Spirit." ${ }^{\text {"4 }}$ Several of the images in the windows explained the different processes by which Persian crude oil was

${ }^{42}$ Hull Daily Mail, 20 March 1924, 3; Flight, 5 June 1924, 374.

${ }^{43}$ Anglo-Persian Oil Company/British Petroleum Company, Wembley (postcard), 1924.

44 “The Company's Exhibit at Wembley," Naft 1, no. 4 (April 1925): 35. 
found, extracted, and refined, while others showed the dramatic transformations of local landscapes in the mountains of southwest Persia. A series of smaller

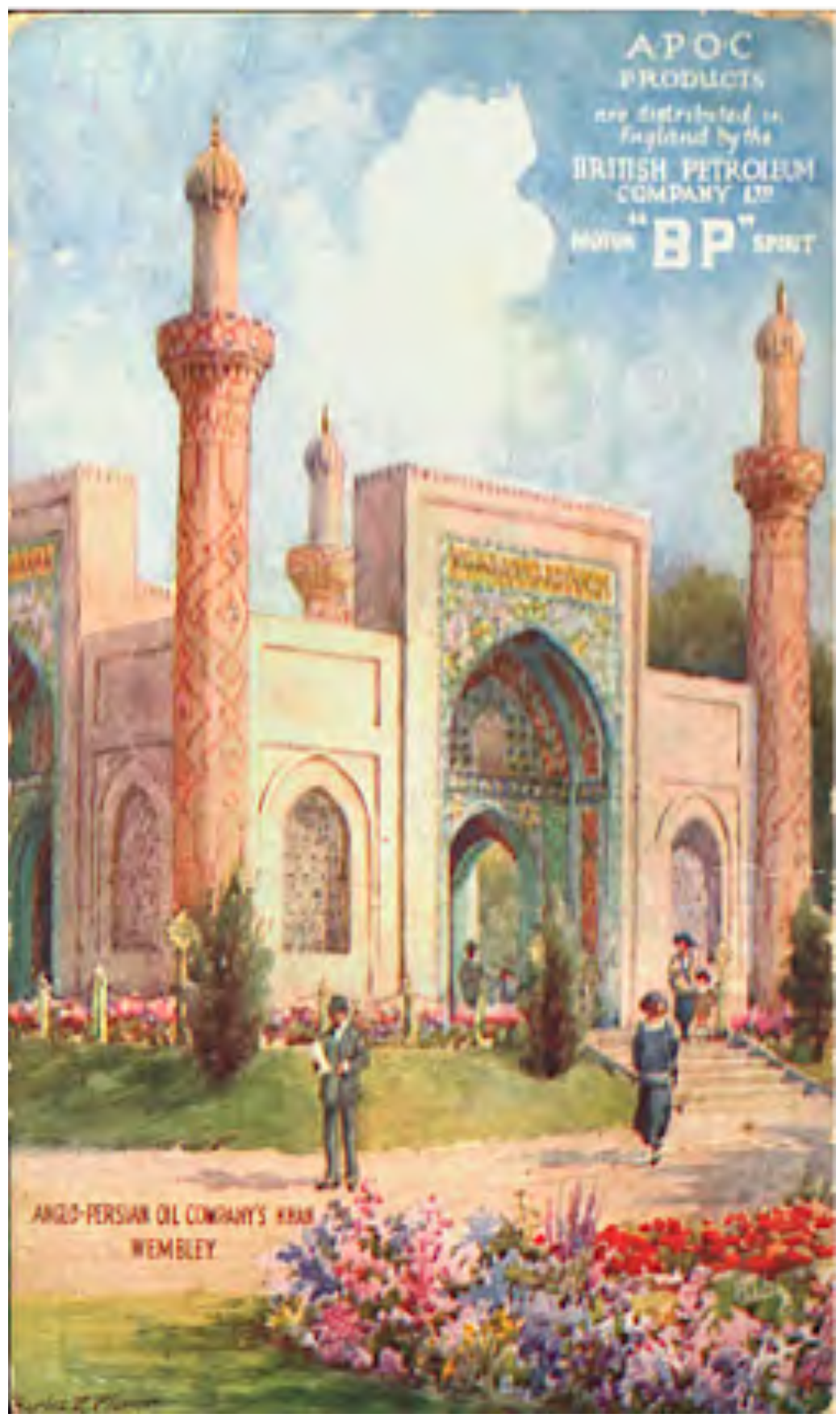

Figure 3: Postcard distributed by BP staff at the Persian Khan exhibit British Petroleum, Wembley (postcard), 1924 
windows around the top of the showcase depicted various oil fuelled technologies of the day: a tractor working a field, a fleet of BP delivery vehicles, and an open-cockpit race car.

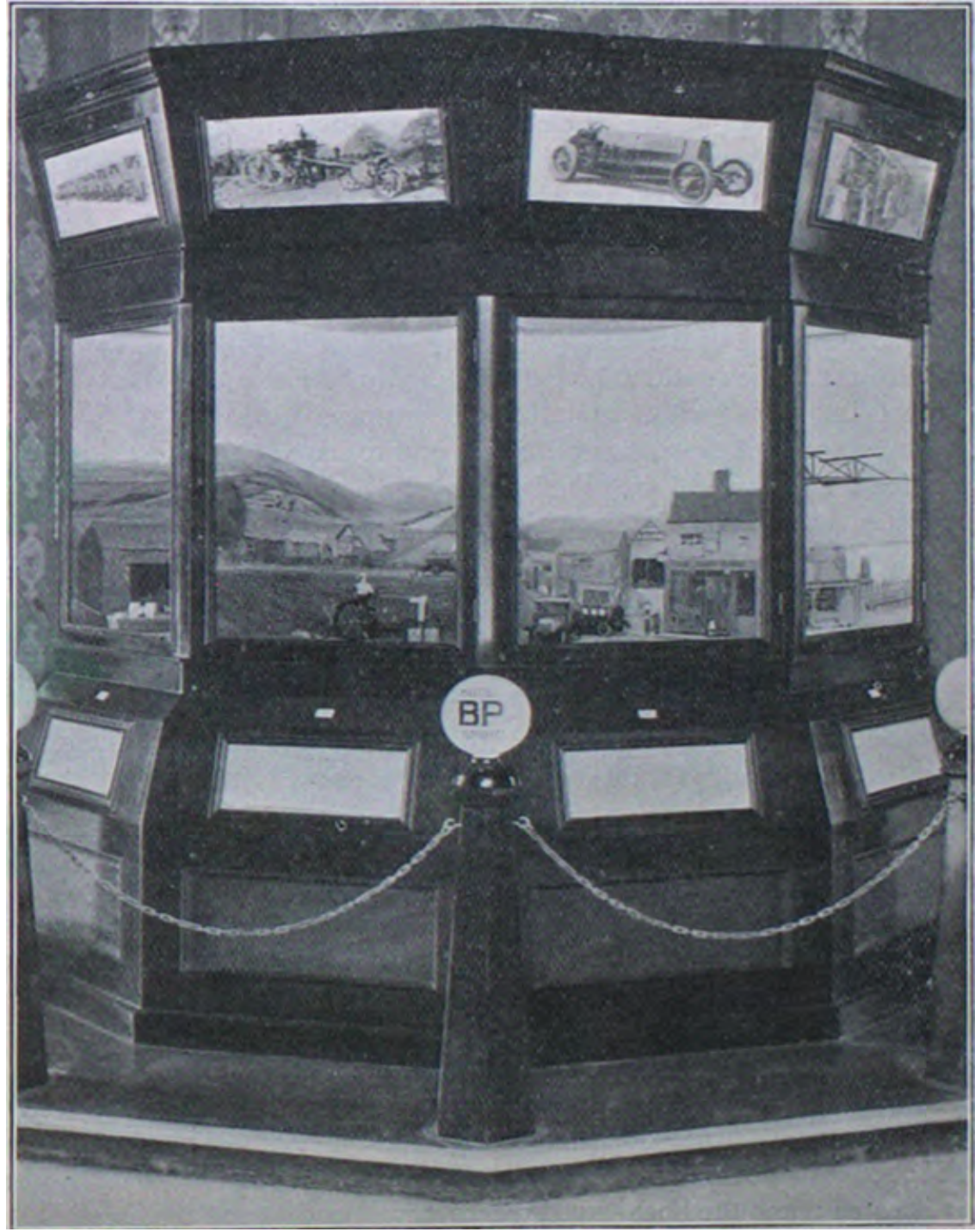

Figure 4: Mahogany Showcase located inside BP's Persian Khan exhibit BP, Naft, April 1925

The contents of the showcases told the same story that Braithwaite had been developing in his Persian-inspired print advertising campaigns; namely, that modern science and technology had been marshalled in exotic Persia in order to produce a powerful and reliable motor spirit for the pleasure of the British motorist. The showcase design, however, was distinctly Victorian, 
which had the effect of reaching into the past, while the modern technologies contained inside them produced a sharp entry into the future. To further underscore the transition from the ancient past to the modern future, the interior of the Khan was decorated with large pieces of art depicting scenes of Persian life and culture. ${ }^{45} \mathrm{~A}$ visit to the Khan exhibit offered guests a chance to take part in BP's imaginative story of oil: a story in which modern Britain triumphed over ancient Persia.

BP hosted several publicity events at the Persian Khan exhibit, which were intended to communicate the company's messages about ancient Persia and modern oil to targeted audiences beyond the regular admission visitors. In July 1924, Sir Charles Greenway, the Chairman of APOC, hosted an exclusive dinner for eighty guests at the Lucullus Restaurant, located on the grounds of the BEE. The dinner brought together major figures in the British and American oil industries, including A.C. Bedford and W.C. Teagle, the Chairman and President, respectively, of Standard Oil New Jersey. Following the meal, the guests were taken on a private tour of the Khan, and a group photograph was taken on the stairs inside one of the high-arched entryways. ${ }^{46}$ In October 1925 , during the second iteration of the BEE, BP board members hosted a luncheon at the Lucullus for the Management Committee of the Société Générale des Huiles de Pétrole, BP's sister company in France. This delegation was also given a private tour of the Khan exhibit, which was led by members of the BP Advertising Department, including Braithwaite and Watts. ${ }^{47}$

The largest component of BP's strategy to promote the Persian Khan exhibit, however, took the form of an advertising campaign launched in British newspapers and magazines during the summer driving seasons of 1924 and 1925. The BEE advertisements featured drawings and photographs of the Khan exhibit, as well as a section of text that explained what visitors could expect to see upon their arrival at the installation. What makes these advertisements particularly fascinating is their integration with other elements of BP's motor spirit marketing strategy, and the combining of print advertising, outdoor advertising, and public exhibition techniques into a single campaign. The first advertisements for the Persian Khan exhibit were published in June 1924, under the series title "B.P. at Wembley." They appeared in numerous newspapers and magazines in which the company had run advertisements in the past, including the Illustrated London News, Graphic, Tatler, and The Times, and they featured

${ }^{45}$ Naft, April 1925, 35.

${ }^{46}$ Invitation Card from the Chairman and Directors of the Anglo-Persian Oil Company, 24 July 1924. BP Archives, ARC 210927.

47 “A Real Entente Cordiale,” Naft 1, no. 3 (January 1925): 10. 
several large drawings and photographs of the Khan exhibit. ${ }^{48}$ A visit to the company's "distinctively Persian building," explained one advertisement published in the Sphere, with its "slender minarets and its blue-and-green tiled doorways," would provide "a reminder of the beauty and ancient splendour of the Land of the Shahs." 49 Inside the exhibit, the ad continued-visitors could expect to hear stories about the "source of crude oil which is brought to Great Britain," and to learn of the "engineering and chemical skill and the immense business organisation engaged in the task of production, refining, and distribution." 50 The advertisement highlighted the five educational display cases placed in the exhibit and their effectiveness in guiding visitors "through Persia and every phase in the production of the oil from which 'BP,' the British Petrol, is refined." 51

Another print advertising campaign was launched for the second BEE held in 1925, which was a series of new advertisements under the titles "AngloPersian Oil Company and BP Motor Spirit at Wembley" and the "Persian Series" that appeared in the same publications as in the previous year. ${ }^{52} \mathrm{~A}$ distinguishing feature of the 1925 advertisements was the use of more evocative imagery and stories. In one example entitled "Transporting Pipe Line in Persia," BP claimed to have bridged "the great gulf of the centuries" that separated the ancient world and the modern world, using its privileged knowledge of Persian geography and employing a vast arsenal of advanced oil technologies. ${ }^{53}$ In making these spatial and temporal connections, the company claimed to have brought to all "not the prosperity...won by the sword in distant days, but that which is based on a genuine contribution to the welfare and needs of the world." "54 This apparently benevolent extraction of oil was something of which British motorists could be rightfully proud; one advertisement asserted it was "part of the romance of modern industry that the great subterranean sources of petroleum, feeding the oil-springs from which the Arab skimmed his pitch, should to-day furnish the British motorist with the fuel for his car," 55 while another advertisement confirmed to British readers, with more than a hint of satisfaction and superiority, that the highpoint of Persian culture had crested,

${ }^{48}$ Tatler, 21 May 1924, 79; Sketch, 21 May 1924, 81; The Times, 24 May 1924.

${ }^{49}$ Sphere, 31 May 1924, 45.

${ }^{50}$ Graphic, 31 May 1924, 35.

${ }^{51}$ Motor Cycle, 12 June 1924.

${ }^{52}$ Times, 8 July 1925, 11.

${ }^{53}$ Illustrated Sporting and Dramatic News, 13 June 1925, 53.

${ }^{54}$ Illustrated London News, 9 May 1925, 50.

${ }^{55}$ Sphere, 2 May 1925, 43. 
eclipsed by more powerful, more modern oil-burning empires: "Gone are the captains and kings. Their citadels are crumbled to dust." 56 Through these stories of rise and decline, BP created an imagined geography of oil in which the vast natural treasures of mysterious Persia were unlocked by modern science, technology, and BP, for the benefit of the British motorist.

The print advertisements published for the 1925 Persian Khan added more details about the information that visitors would receive. "The story of a great national enterprise is told in attractive tableaux," claimed an advertisement published in the Illustrated London News in August 1925. ${ }^{57}$ Another advertisement claims that "the interior of the exhibit was designed to convey an impression of the more important points in the sequence of activities... necessary before 'BP' reaches the motorist." ${ }^{58}$ An advertisement published in The Times in July focused on the educational aspects of BP's installation at the BEE, and featured an illustration of a man and woman inspecting the ten-sided mahogany showcase at the centre of the exhibit. ${ }^{59}$ The male figure, dressed in a coat and wearing a hat, points to one of the showcase's backlit panels, which depicted a cross-section diagram of an oil well and drill bit descending through different strata of rock. The female figure, dressed in a coat and wearing a flapper's hat, also gazed intently at the diagram. The text accompanying the image encouraged the reader to visit the Persian Khan so that they, too, could "learn of the great organization that produces 'BP," and of the "scientific production methods and up-to-date refinery processes which make 'BP' the best of all motor spirits." ${ }^{\prime \prime 0}$ Another advertisement included a large photograph of the Persian Khan exhibit at night, surrounded by dozens of visitors. The figures were all partially blurred, which gave the impression of movement and the hum of a bustling crowd. Beams of light emanate from the exhibit's decorated high-arched doorway on to the visitors, bathing them in a dull glow. [Figure 5].

\footnotetext{
${ }^{56}$ Bystander, 17 June 1925, 69.

57 Illustrated London News, 15 August 1925, 327.

${ }^{58}$ Illustrated Sporting and Dramatic News, 25 July 1925, 58.

59 The Times, 8 July 1925, 11.

${ }^{60}$ See note 59.
} 


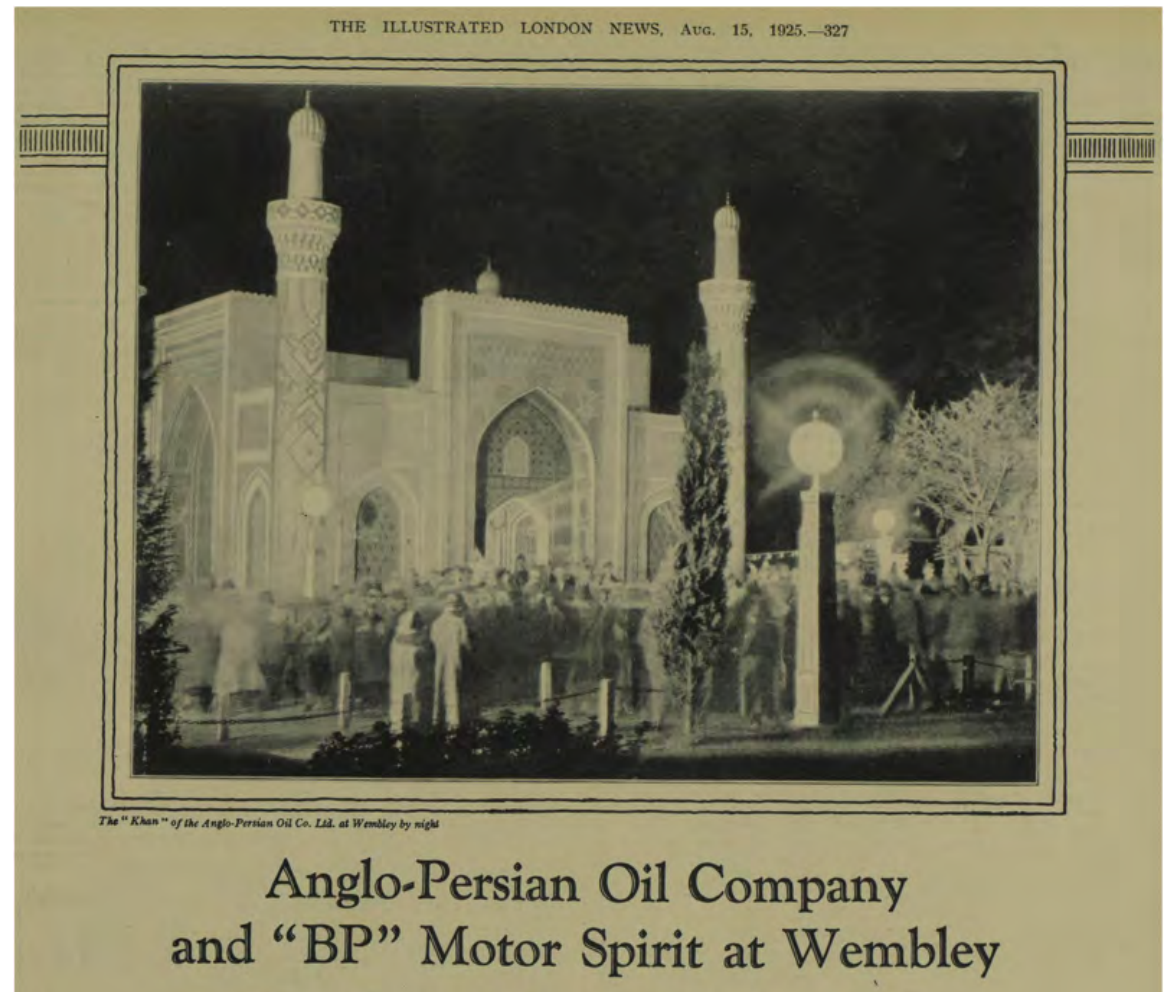

The story of a great national enterprise is told in attractive tableaux in the exhibit of the Anglo-Persian Oil Co. Ltd. at Wembley.

The building itself, which is situated at the east end of the lake, represents a Persian "Khan" or caravanserai such as is found along the caravan routes in Persia where travellers rest from the journey.

The interior exhibit is designed to convey an impression of the more important points in the sequence of activities of the Compant from the production of crude oil up to the distribution of " $\mathrm{BP}$ " Motor Spirit and other products - drilling for oil in the Persian fields, conveying the crude oil in British ships to this country refining at Llandarcy in South Wales, distributing the finished products by rail tank-cars, can-filling operations and the many other activities necessary before " $\mathrm{BP}$ " reaches the motorist.

$A$ visit to the "BP" exhibit will give you a wider and deeper realisation of the great importance of British Petrol, not only to th British motorist but to the Empire at large.

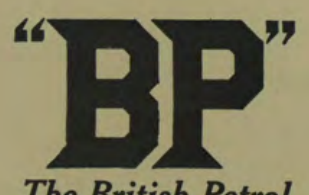

The British Petrol

British Petroleum [..Ltd Britannic House.Moorgate.E.C.2 Distributing Orqanization of the ANGLO-PERSIAN OIL CO LTD.

Figure 5: "Anglo-Persian Oil Company and 'BP' Motor Spirit at Wembley" Illustrated London News, 15 August 1925 
A review of the press coverage associated with the exhibit illustrates the significant impact that the company made at the BEE. Flight magazine published a photograph of the "characteristic and beautiful pavilion," in front of which was parked the company's oil delivery wagon, prominently displaying the letters BP, while inside the Khan, visitors would learn from a series of "interesting and comprehensive" showcases, illustrating the "various processes and stages in the manufacture of B.P. motor spirit and other products of the Anglo-Persian Oil Co." ${ }^{61}$ The Illustrated London News also commented on the "romantic story" that was told through the five showcases featured in BP's exhibit, as did the Petroleum Times and Tatler. ${ }^{62}$ News of the Persian Khan spread to places far beyond London and southeast England. The Aberdeen Press and Journal wrote that the exhibit "carries the mind back to the beauty and mystery and ancient splendour of Persia." 63 Through a series of showcases containing "tangible exhibits of machinery and products," the newspaper explained, BP told the "romantic story" of oil's journey from Persia to Britain. The Persian Khan's collection of artefacts, images, and stories about oil had the effect of producing a "vivid illustration of the extent to which Empire oil now enters into daily life." ${ }^{\prime}$ The Belfast News Letter reported to its readers that BP's exhibit highlighted the "extraordinary blend of East and West which the history of the company presents," and told visitors the story of "one of the greatest and most successful British commercial enterprises of modern times." ${ }^{\prime \prime}$

\section{Conclusion: BP's Khan and the Commercial Conquest of Persia}

The aim of this article has been to reconstruct the processes by which BP marketed its motor spirit products in 1924 and 1925, in particular its Persian Khan exhibit, and to reveal the important function these narratives performed in the making of British petroculture. Though there exists a large body of scholarship on the economic and political aspects of oil during this period, energy historians have neglected the ways in which oil companies like BP marketed their products to diverse audiences of British consumers. The literature's silence on these marketing activities has meant that historians have not yet accounted for all of the ways in which oil was imagined in early twentieth century Britain.

${ }^{61}$ Flight, 5 June 1924, 374.

62 Illustrated London News, 7 June 1924, 1093; Petroleum Times, 24 May 1924, 740.

${ }^{63}$ Aberdeen Press and Journal, 31 May 1924, 4.

${ }^{64}$ Aberdeen Press and Journal, 31 May 1924, 4.

${ }^{65}$ Belfast News Letter, 4 June 1924, 4. 
In 1919, BP had next to no serious marketing materials. During the early 1920s, under the leadership of executives like Watts and Braithwaite, BP developed a comprehensive motor spirit marketing campaign designed to attract attention to BP Motor Spirit and encourage its consumption. As the minutes of the board make clear, the company invested heavily in a variety of different marketing activities aimed at creating a coherent brand identity. The Publicity Department's first campaign concentrated on outdoor advertising initiatives that included the placement of posters and roadside signs, and the branding of company-owned shipping vessels, rolling stock, and motorized delivery vehicles. The goal of these campaigns was to raise awareness of the BP brand and its products, showcasing the company's identity in simple yet eye-catching ways.

A central component of BP's marketing of the mid-1920s was the presentation of information and ideas about Persia, the country from which BP's parent company, APOC, acquired supplies of crude oil. Starting in 1924, the company's motor spirit marketing began to include Persian subjects, which presented stories of cultural collision in exotic foreign lands. In these stories, the modern British motorist was configured as the beneficiary and deserving heir to the buried natural treasures sitting idly beneath foreign Persian landscapes. APOC and BP had successfully launched a commercial conquest of Persia, and a seemingly unlimited supply of motor spirits was the prize.

The pinnacle of BP motor spirit marketing during the 1920s was the company's Persian Khan exhibit, presented at the BEE in 1924 and 1925. The Khan combined the most effective storytelling techniques that the company had devised in its earlier outdoor and print advertising campaigns, highlighting how far BP's marketing strategy had come since 1919. The exhibit utilised messaging techniques that mixed education and entertainment. It told the story of commercial conquest on behalf of the British consumer, and the immense energy that was required to deliver BP motor spirit to the nozzle-tip at the local filling station. The Persian Khan represented an oil spectacle in every sense, constructed to leave British audiences in awe about Persian oil and its power to transform daily life. As with all BP motor spirit marketing activities undertaken during these formative years in the company's history, the Khan was designed to capture not only market share, but also the imaginations of British motorists.

This article was structured upon two driving questions. How did BP market its motor spirit products during the mid-1920s, specifically its Persian Khan exhibit of 1924 and 1925? What images and ideas did BP use to tell the story of oil's journey from Persia to Britain, and how were these presented in the exhibit? To answer these questions, this article has reconstructed the history 
of the 1924-1925 Persian Khan exhibit and its associated publicity. In doing so, it has asserted that BP's early motor spirit marketing campaigns offer valuable insight into the ways in which oil was interpreted and imagined in Britain during the early twentieth century. The Khan was designed to attract the attention of audiences, persuade them to purchase BP products, and thereby increase the company's market share. Much more than a commercial stunt, however, the Persian Khan represented an archive of creative images and stories about oil, which encouraged and directed consumers to think about the resource in new ways. As a communicative tool that worked to educate audiences about what oil was, where it was found, how it was extracted, and by whom it was consumed, BP's exhibit can be understood as a corporate effort to "narrativize" oil and its daily use.

In BP's imagined world of oil, the best motor spirits were those which came from distant, exotic and ancient Persia, and which were extracted and refined using modern British science and technology. Although at the first glance the Persian Khan appears to offer a broad spectrum of information about Persian history, culture, and geography, a closer reading reveals that the images and narratives employed by BP actually strove to render Persia as a wild landscape that was empty of life and culture, and therefore ripe for exploitation. Specifically, the imaginary petro-world that is rendered in the exhibit constructs oil as an exotic subterranean prize held captive beneath inhospitable landscapes, but which in 'modern times' had been unlocked by a company that wielded technology as its weapon and consumerism as its mandate to extract ever increasing amounts of oil. In this teleological story of discovery and exploitation, the 'modern British consumer' was configured as the central character, and the deserving heir to the buried natural treasures sitting idly beneath remote and empty terrains.

All knowledge about oil exists within a complex matrix of historical conflict, bound up and interwoven with the past in ways that are often difficult to tease apart. In the mid-1920s, the sense of entitlement to unlock, own, and expend the Persia's oil resources was couched in the language of imperialism, and the discovery of new oil resources became symbolic of British (and BP's) scientific prowess and mastery over the natural environment. 


\section{Works Cited}

Barrett, Ross and Worden, Daniel. "Oil Culture: Guest Editors' Introduction." Journal of American Studies 46 (2012): 269.

Barrett, Ross and Worden, Daniel (eds.). Oil Culture. Minneapolis, MN: University of Minnesota Press, 2014.

Brown, Robert. “Cultivating a 'Green' Image: Oil Companies and Outdoor Publicity in Britain and Europe, 1920-1936." Journal of European Economic History 22, no. 2 (Fall 1993): 350.

Clarke, Travers. "British Empire Exhibition: Second Phase." $19^{\text {th }}$ Century 97 (Feb. 1925): 175.

Clendinning, Anne. "Exhibiting a Nation: Canada at the British Empire Exhibition, 1924-1925." Social History 39, no. 77 (2006): 79-107.

Ferrier, R.W. "Petrol Advertising in the Twenties and Thirties: The Case of the British Petroleum Company." European Journal of Marketing 20, no. 5 (1986): 29-51.

Geppert, Alexander C.T. Fleeting Cities: Imperial Expositions in fin-de-Siècle Europe. London: Palgrave Macmillan, 2010.

Johnson, Bob. Carbon Nation: Fossil Fuels in the Making of American Culture. Lawrence, KS: University Press of Kansas, 2014.

Jones, Geoffrey. The State and the Emergence of the British Oil Industry. London: Macmillan, 1981.

Kent, Marian. Oil and Empire: British Policy and Mesopotamian Oil, 19001920. London: Macmillan, 1976

Lawrence, George Clarke (ed.). Official Guide to the British Empire Exhibition. London: Fleetway, 1924.

LeMenager, Stephanie Living Oil: Petroleum Culture in the American Century. New York: Oxford University Press, 2014.

MacKenzie, John M. Propaganda and Empire: The Manipulation of British Public Opinion, 1880-1960. Manchester: Manchester University Press, 1984.

Paterson, Matthew and Dalby, Simon. "Empire's Ecological Tyreprints." Environmental Politics 15 (2006): 2-3. 
Szeman, Imre. "How to Know About Oil: Energy Epistemologies and Political Futures." Journal of Canadian Studies 47 (2013): 145-68. 